\title{
Inhibition Activities of Fish Oil in iNOs, COX-2, and $\beta$-Catenin Expressions in Colorectal Preneoplasia of Mice Induced by Azoxymetane and Dextran Sodium Sulfate
}

\begin{abstract}
Kusmardi
Student of Animal Biomedical Science Program, Postgraduate School of Bogor Agricultural University, Bogor, Indonesia

Department of Anatomic Pathology, Faculty of Medicine, University of Indonesia, Jakarta, Indonesia
\end{abstract}

Bambang Pontjo Priosoeryanto

Laboratory of Pathology, Department of Clinic, Reproduction and Pathology, Faculty of Veterinary, Bogor Agricultural University, Bogor, Indonesia

\section{Eva Harlina}

Laboratory of Pathology, Department of Clinic, Reproduction and Pathology, Faculty of Veterinary, Bogor Agricultural University, Bogor, Indonesia

\section{Santoso Cornain}

Department of Anatomic Pathology, Faculty of Medicine, University of Indonesia, Jakarta, Indonesia

Received: August 8, 2014 Accepted: September 8, 2014 Published: September 11, 2014

Doi: 10.5296/jab.v2i2.6294 URL: http://dx.doi.org/10.5296/jab.v2i2.6294

\begin{abstract}
Epidemiological studies of the relationship between dietary fish oil and risk of colorectal cancer have been inconsistent. The present study was conducted in order to determine the
\end{abstract}


inhibitory effect of fish oil on inducible nitric oxide synthase (iNOS), cyclooxygenase (COX)-2, and $\beta$-catenin expressions in the colorectal preneoplasia development of mice induced by azoxymetane (AOM) and dextran sodium sulfate (DSS). In this study, balb/c mice was injected intraperitoneally by a single dose of $10 \mathrm{mg} / \mathrm{kg}$ of body weight AOM followed by administere of $1 \%$ DSS during a week in drinking water. Fish oil was administered orally in three different doses $(1.5 \mathrm{mg} /$ low dose, $3 \mathrm{mg} /$ medium dose and $6 \mathrm{mg} / \mathrm{high}$ dose $)$ in each group of mice per day until the mice were terminated. The expression of iNOs, COX-2, and $\beta$-catenin were observed in the epithelial cells of colon mucosa crypts. In the second month, the iNOs expression was decreased in the medium and high groups of fish oil. In the third and fourth month, decreasing of the iNOs expression were observed in all groups $(\mathrm{p}<0.05)$. The COX-2 expression was decreased in the medium and high groups on the second month. The expression of $\beta$-catenin was also decreased in the medium group on the fourth month. The inhibition effect of high dose of fish oil on $\beta$-catenin was observed on the third month. In conclusion, administration of medium dose of fish oil in mice induced by AOM/DSS was the most effective dose to decreased the expression of iNOs, COX-2, and $\beta$-catenin in the second month.

Keywords: Azoxymetane, $\beta$-Catenin, COX-2, Colorectal cancer, Fish oil, iNOs

\section{Introduction}

Several research have shown that the development of colorectal cancer associated with nutritional factors. Fish oil is a substance containing poly-unsaturated fatty acid (PUFA) such as $\omega$-3-eicosapentaenoic acid (EPA) and docosahexaenoic acid (DHA), which play a role in inducing cellular apoptosis and differentiation, as well as inhibiting cell proliferation. Accumulation of $\omega-3$ PUFAs on the cell membrane are predicted to maintain the fluidity, receptor binding to its ligand, determine the activity of the enzymes such as ornithine decarboxylase (ODC), and transduction pathways (Moreira et al., 2009).

Except the nutritional factor, colorectal carcinogenesis is also associated with inflammation that occurs in colorectal. Ulcerative colitis (UC) and inflammatory bowel disease (IBD) increases the potential to develop colorectal cancer (Sergei et al., 2010). The occurrence of inflammation in the colorectal crypt epithelial led to the formation of inducible nitric oxide synthase (iNOS) and cyclooxygenase-2 (COX-2) which resulted in upregulation of the production of prostaglandin E2 (PGE2) and nitric oxide (NO). Both of these molecules causes an increase in reactive oxygen species (ROS). ROS lead to a variety of damage to both protooncogene genes and tumor suppressor genes. The damages caused by ROS stimulates the initiation development of gene in normal epithelial cells become preneoplastic and neoplastic cells (Ridnour et al., 2008). $\beta$-catenin is one of the tumor supressor genes related to the development of colorectal cancer. Mutation of $\beta$-catenin gene resulted in $\beta$-catenin protein overexpression in cytoplasm and nuclear of colorectal crypt epithelial cell (Gochman et al., 2012). Research in expression of $\beta$-catenin as a result of upregulation iNOS production and COX-2 in colorectal epithelial cells of mice that administered by supplement of fish oil, is expected to give some informations regarding to the effect of fish oil on the expression of the three proteins in colorectal carcinogenesis, especially those it preced by inflammation. To obtain a model of colorectal carcinogenesis which is preceded by inflammation, mice were induced by azoxymetane (AOM) as a genotoxic substance, and dextran sodium sulfate (DSS) as compound that stimulate 
inflammation.

\section{Methods}

\subsection{Experimental Animal}

Male Balb /C mice aged 5 weeks were obtained,maintained and treatedin the Laboratory of Experimental Pathology, Department of Anatomic Pathology, Faculty of Medicine, University of Indonesia. Animals are maintained and treated according to the Guide for Care and Use of Laboratory Animals of the Animal Care and Use Committee, and was approved by the Research Ethics Committee of the Faculty of Medicine, University of Indonesia. Mice were maintained in a temperature-controlled conditions at $23{ }^{\circ} \mathrm{C}$ and $55 \%$ of humidity with a cycle of 12 hours light/dark. Mice were fed standard food in both of the control group and the test group. Additionally, the test group was given fish oil with a dose of $1.5 \mathrm{mg}, 3 \mathrm{mg}$ and 6 mg per mouse per day.

\subsection{Induction of Colon Preneoplasia by AOM and Dextran DSS}

Induction of colon preneoplasia of mouse is done by intraperitoneal injection of AOM dissolved in $0.9 \% \mathrm{NaCl}$ with dose of $10 \mathrm{mg} / \mathrm{kg}$ of body weight. Mice were given standard food and drink mineral water for one week after induction. Furthermore, for the next one-week treatment, the mineral water is replaced by mineral water containing $1 \%$ of DSS (Suzuki et al., 2006; Tanaka et al.,2003). Research protocol is displayed in Figure 1.

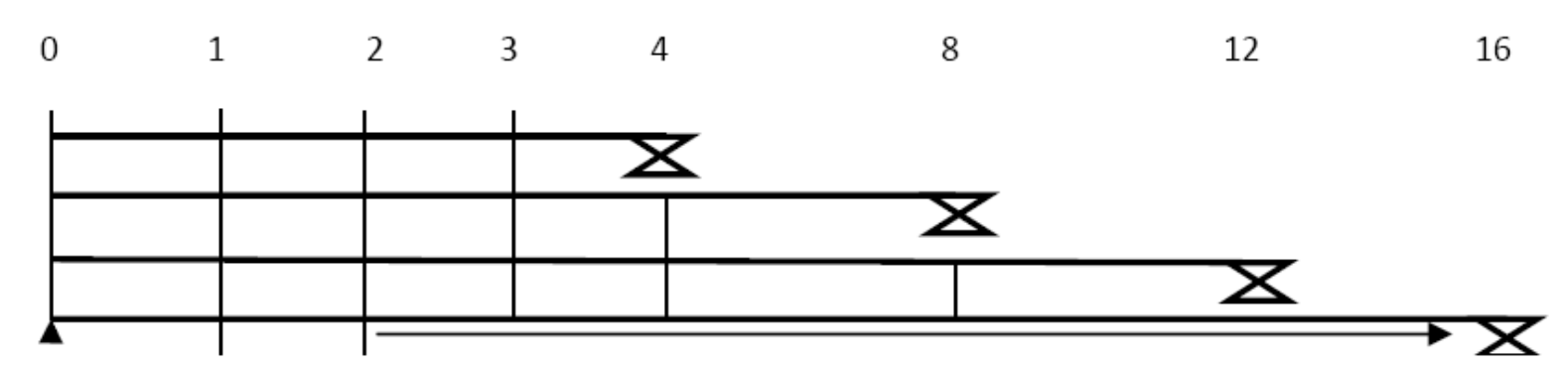

AOM DSS Fish Oil

Figure 1. Research protocol. Intraperitoneally injected AOM $10 \mathrm{mg} / \mathrm{kgBW}, 1 \%$ DSS was given through mineral water, fish oil was given orally $\boldsymbol{Z}$ means mice were sacrificed; number is refer to weeks)

\subsection{Tissue Sample Preparation}

Mice were sacrificed by using ether after $4,8,12$, and 16 weeks of carcinogenesis induction by AOM. Colon tissues of mice were taken, then cleaned from the lumen of the colon with water. Tissue was fixed with $10 \%$ of phosphate buffered formalin.

\subsection{Immunohistochemistry Staining of iNOS, COX2 and $\beta$-catenin}

Tissues sample was cut with a thickness of $4 \mu \mathrm{m}$ for immunohistochemistry staining. After deparaffination and rehydration, specimens weredyed by $0.01 \mathrm{M}$ of citrate buffer $(\mathrm{pH} 6.0)$ in microwave for 5 minutes. Specimens were spilled by 3\% of hydrogen peroxide to eliminate endogenous peroxide for 5 minutes at room temperature. Specimens were incubated with 
rabbit polyclonal antibodies of inducible nitric oxide synthase (1:200 dilution; Abcam Inc., Cambridge, MA) or rabbit polyclonal cyclooxygenase-2 (1:100 dilution; Cell Signaling Technologies, San Diego, CA), or rabbit polyclonal $\beta$-catenin (1:250 dilution; Abcam Inc., Cambridge, MA) in PBS for 2 hours at room temperature in a humidity chamber, followed by overnight incubation at $4{ }^{\circ} \mathrm{C}$. N-Universal (Dako)was used as a negative control. Specimenswere then incubated with the appropriate secondary antibody for one hour at room temperature, followed by incubation with HRP-conjugated streptavidin for 30 minutes. Proteins visualized using 3,3'-diaminobenzidine (DAB) for 10 minutes at room temperature. The specimens was added counterstain with Harris hematoxyllin, dehydrated and mounting.

\subsection{Immunohistochemistry Staining Interpretation}

Inducible NOS and COX-2 expression in the cytoplasm and $\beta$-catenin expression in the membrane and cytoplasma of colon crypt epithel cell was scored semiquantitatively by using Walker criteria in 10 visual fields with $400 \mathrm{x}$ magnification. The scoring of expression was defined as: $0=$ negative, $1 \leq 10 \%$ cells stained, $2=10-50 \%$ cells stained, $3=51-80 \%$ cells stained, $4=81-100 \%$ cells stained. The total expression score was summed, and then the average value was counted (Walker, 2006). As the positive control of iNOS and COX-2 staining were used tonsil tissues, meanwhile the positive control of $\beta$-catenin staining were used colon adenocarcinoma tissues. For the negative control of the three stains, there was no additional primary antibody in the same tissue specimen.

\subsection{Data Analysis}

Two-ways analysis of variance (ANOVA) was used to determine the effect of four doses of fish oil (0, 1.5, 3 and $6 \mathrm{mg}$ /day) and duration effect of fish oil administration $(1,2,3$, and 4 months) against colorectal carcinogenesis based on the assessment of the expression of iNOS, COX-2, and $\beta$-catenin. The Tukey multiple comparation test is used to determine the differences between groups. Prior to do ANOVA, the normality of data distribution was tested using the Levene's test, whereas the homogenity of variance was tested using the Kolmogorov-Smirnov test.

\section{Result}

\subsection{Effect of Fish Oil on the iNOS Expression}

Through statistical tests using two-ways ANOVA, indicated a significant difference in the expression of iNOS for each monthly sampling colonic tissue of mice, also shown the differences in the expression of iNOS in each dose of fish oil. The interaction between these two variables was not found $(\mathrm{p}=0.591)$. Through the Tukey multiple comparation test, indicated that in the control group no changes in the expression of iNOS. At low and medium doses,decreasing in the expression of iNOS were found in the fourth month. While in high doses, decreasing in expression of iNOS significantly different occurred from the third month. From a comparison of iNOS expression of each month can be obseved that, in the first month has not found significant differences in iNOS expression. In the second month was found iNOS expression were significantly different in medium doses. Similarly, in the third and fourth month, the use of medium doses could decrease the expression of iNOS (Table 1, Figure 2). 
Table 1. iNOS, COX-2 and $\beta$-catenin expression in colon crypt epithelial cells of AOM/DSS-induced mice and after fish oil administration

\begin{tabular}{|c|c|c|c|c|c|}
\hline Groups & $1^{\text {st }}$ month & $2^{\text {nd }}$ month & $3^{\text {rd }}$ month & $4^{\text {th }}$ month & $\mathrm{P}$ \\
\hline \multicolumn{6}{|l|}{ iNOs } \\
\hline Control & $30.67 \pm 3.46^{\mathrm{ab}}$ & $35.17 \pm 3.06^{\mathrm{b}}$ & $30.83 \pm 2.55^{\mathrm{c}}$ & $28.00 \pm 1,4^{\mathrm{b}}$ & 0.343 \\
\hline Low dose & $34.00 \pm 1.31^{\mathrm{bB}}$ & $34.33 \pm 4.54^{\mathrm{bB}}$ & $24.83 \pm 3.39^{\mathrm{bcAB}}$ & $19.17 \pm 3,53^{\mathrm{abA}}$ & 0.022 \\
\hline Medium dose & $21.67 \pm 3.20^{\mathrm{abB}}$ & $17.83 \pm 3.40^{\mathrm{aAB}}$ & $15.33 \pm 3.27^{\mathrm{abAB}}$ & $13.00 \pm 3,45^{\mathrm{aA}}$ & 0.035 \\
\hline High dose & $15.33 \pm 3.88^{\mathrm{aAB}}$ & $18.00 \pm 3.66^{\mathrm{aB}}$ & $11.33 \pm 3.63^{\mathrm{aA}}$ & $11.67 \pm 3,42^{\mathrm{aA}}$ & 0.013 \\
\hline $\mathrm{P}$ & 0.002 & 0.039 & 0.010 & 0.005 & \\
\hline \multicolumn{6}{|l|}{ Cox-2 } \\
\hline Control & $17.87 \pm 2,52^{\mathrm{ab}}$ & $19.58 \pm 1.34^{\mathrm{b}}$ & $20.63 \pm 2.15^{b}$ & $23.15 \pm 2.97^{\mathrm{b}}$ & 0.456 \\
\hline Low dose & $17.87 \pm 2,52^{\mathrm{ab}}$ & $18.37 \pm 2.27^{\mathrm{bAB}}$ & $13.62 \pm 1.70^{\mathrm{abAB}}$ & $10.78 \pm 1.76^{\mathrm{aA}}$ & 0.020 \\
\hline Medium dose & $19.03 \pm 3,17^{\mathrm{ab}}$ & $11.55 \pm 1.19^{\mathrm{a}}$ & $8.87 \pm 1.64^{\mathrm{a}}$ & $7.70 \pm 1.72^{\mathrm{a}}$ & 0.345 \\
\hline High dose & $8.87 \pm 1,94^{\mathrm{a}}$ & $9.57 \pm 1.14^{\mathrm{a}}$ & $6.87 \pm 1.82^{\mathrm{a}}$ & $7.03 \pm 1.71^{\mathrm{a}}$ & 0.600 \\
\hline $\mathrm{P}$ & 0.018 & 0.000 & 0.000 & 0.000 & \\
\hline \multicolumn{6}{|l|}{$\beta$-catenin } \\
\hline Control & $13.94 \pm 1.97^{\mathrm{A}}$ & $15.28 \pm 1.05^{\mathrm{A}}$ & $13.48 \pm 1.42^{\mathrm{abA}}$ & $18.06 \pm 2.32^{\mathrm{bAB}}$ & 0.279 \\
\hline Low dose & $15.42 \pm 1.62$ & $15.50 \pm 2.19$ & $13.96 \pm 1.16^{\mathrm{a}}$ & $13.44 \pm 1.65^{\mathrm{ab}}$ & 0.774 \\
\hline Medium dose & $14.48 \pm 0.74^{\mathrm{B}}$ & $13.46 \pm 0.88^{\mathrm{AB}}$ & $11.79 \pm 1.56^{\mathrm{aAB}}$ & $9.39 \pm 1.49^{\mathrm{aA}}$ & 0.107 \\
\hline High dose & $13.82 \pm 1.26^{\mathrm{B}}$ & $13.68 \pm 1.05^{\mathrm{B}}$ & $11.86 \pm 1.43^{\mathrm{aAB}}$ & $6.92 \pm 1.51^{\mathrm{aA}}$ & 0.005 \\
\hline $\mathrm{P}$ & 0.053 & 0.213 & 0.088 & 0.018 & \\
\hline
\end{tabular}

Low dose (1.5mg/ day), medium dose ( $3 \mathrm{mg} /$ day), high dose $(6 \mathrm{mg} / \mathrm{day})$. Different capital letters in the same line is different significantly at level $\alpha 0.05$. Different small letters in the same coloum is different significantly at level $\alpha 0.05$.

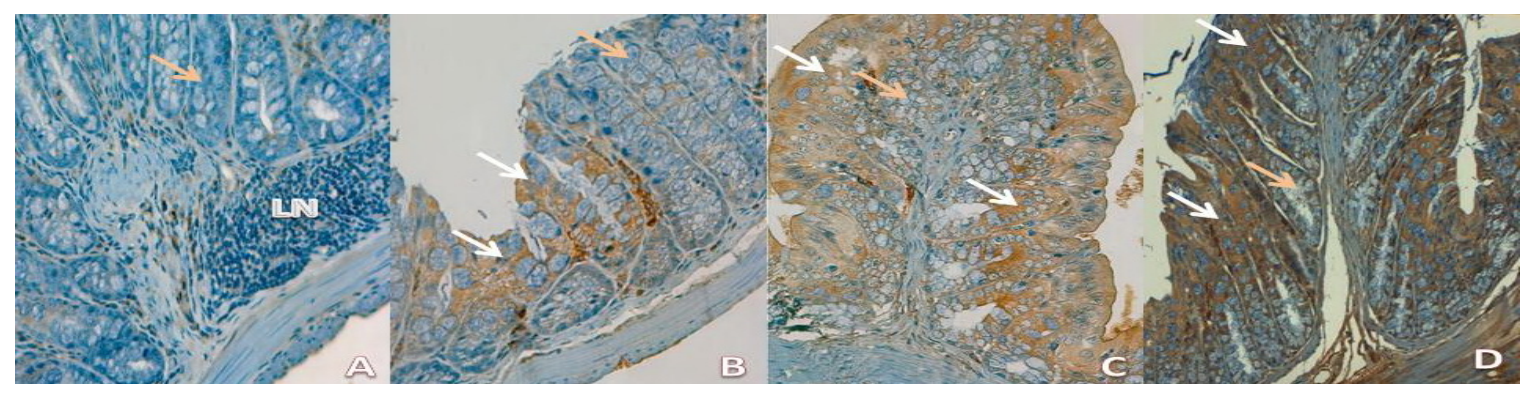

Figure 2. Expression of iNOS in colonic mucosal tissue of mice induced by AOM and DSS and had been given fish oil. A. Score 0 (negative), high dose group, $4^{\text {th }}$ month; B. Score 1 , high dose group $2^{\text {nd }}$ month; C. Score 2, control dose group $3^{\text {rd }}$ month; D. Score 3, control group $4^{\text {th }}$ month. LN: lymph node, yellow arrows: negative iNOS expression, white arrow: positive iNOS expressions, $400 \times$ magnification

\subsection{Effect of Fish Oil Administration on COX-2 Expression}

ANOVA test indicated that the administration of doses of fish oil has changes the expression of COX-2 in the AOM and DSS-inducedmice (Table 1, Figure 3). ANOVA test also showed that duration of administration of fish oil resultedsignificantly changes in the expression of 


\section{Macrothink}

COX-2 in colon tissue of mice. Through this testing, has been found no interaction between duration of administration (in months) and the doses ( $p=0.120)$.

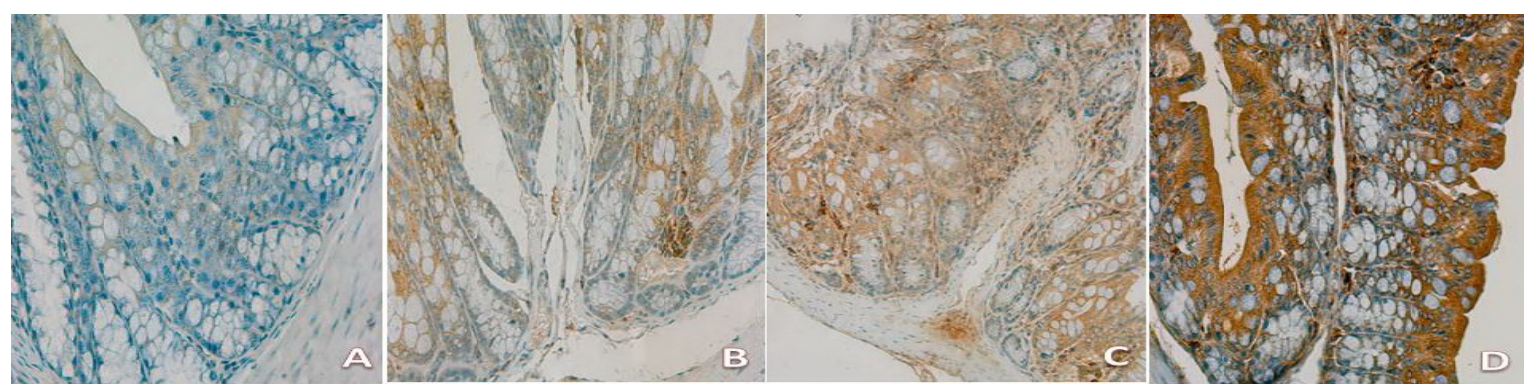

Figure 3. COX-2 expression in the mice colon mucosal tissue induced by AOM and DSS and given fish oil.A. Score 0 (negative), high dose group in the fuorth month; B. Score 1, high dose group in the second month; C. Score 2, control group third month; C. Score 3, control group fourth month. Magnification 400×

\subsection{Fish Oil Effect on $\beta$-catenin Expression}

Through the analysis using ANOVA has been known that there are significant effectbetween duration time and doses of fish oil administration with the expression of $\beta$-catenin in the membrane and cytoplasm of crypt epithelial cells colonic mucosa. However, no interaction was found between duration and doses of fish oil administration $(p=0.097)$. $\beta$-catenin expression in the epithelial crypt cells showed a tendency to increase in control mice in the first month than in the fourth month. At the low doses, has not been found $\beta$-catenin expression changes from first month to fourth month. Decreased expression of $\beta$-catenin occurred in the fourth month in mice given fish oil in medium and high doses. The tendency of a decreasing in the expression of $\beta$-catenin at both doses occurred since the second month (Table 1, Figure 4). The multiple comparation analysis showed significant differences occurred in the expression of $\beta$-catenin colonic crypt epithelial cells in the fourth month by administration of fish oil in medium and high doses.

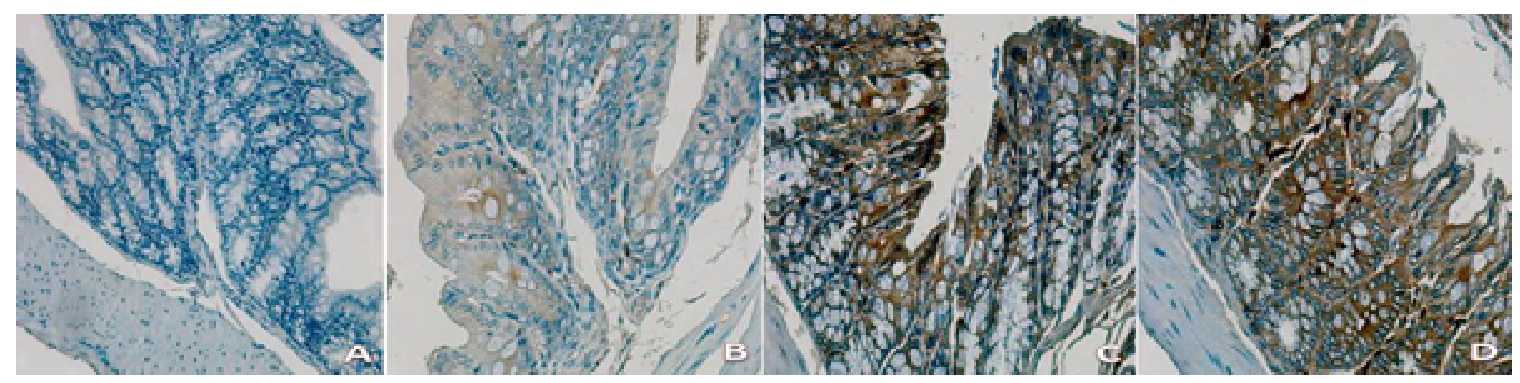

Figure 4. $\beta$-catenin expression in AOM and DSS induced-mice colon tissue and administered fish oil. A. Score 0 (negative) high dose fish oil group at the $4^{\text {th }}$ month; B. Score 1 , high dose groupat $2^{\text {nd }}$ month; C. Score 2 , low dose group at the $3^{\text {rd }}$ month; D. Score 3 , control group at the $4^{\text {th }}$ month. Magnification $400 \times$ 


\section{Discussion}

\subsection{Fish Oil Administration effect on iNOS Expression}

Inducible nitric oxide synthase (iNOS) is an enzyme produced primarily in the inflammation that plays a role in the syntesis of nitric oxide (NO). NO synthesis occurs in large quantities in chronic inflammation and tumor progression. The role of this enzyme in carcinogenesis is not clear. Tissuewith colitis and colon cancer will increase expression of iNOS and nitrotyrosine. In addition it is also stated that there was a dose-dependent relationship between the expression of NO with tumor response. Increasing of iNOS activity in colonic tissue associated with mucosal lesions, ulceration, intraluminal bleeding, colonic dilatation and dysfunction. Increasing the expression of iNOS protein and mRNA were found in acute colitis of induced-animal models accompanied by neutrophil infiltration, edema, and colon tissue damage. The experimental studies using animal models induced by AOM showed the increasing activities and iNOS expression in colon mucosal lesions and other disorders (Gochman et al., 2012).

Our data showed that administration offish oil started to show a decreasing in the expression of iNOS since the second month using medium doses $(3 \mathrm{mg} /$ day $)$. The results are consistent with previous studies that reported the administration of fatty acids contained in fish oil have an inhibitory effect in mice induced colon cancer (Gravaghi et al., 2011). Other studies using 1,2-dimetilhidrazin $(\mathrm{DMH})$ to induce rat colorectal cancer which resulted in decreasing of expression of iNOS colonic crypt epithelial cells and increase the apoptosis of crypt epithelial cells after administration of $\omega-3$ PUFA (Jia et al., 2008). Administration of $\omega-3$ PUFA decreased iNOS in colorectal cancer cells in AOM-induced mice. Decreasing occurs because production of iNOS as a substance produced in the inflammatory process has decreasedwith degree of inflammation. In colorectal cancer carcinogenesis through inflammation, administration of $\omega-3$ PUFA could inhibit inflammation andcause the subsequent carcinogenesis process does not occur (Burlamaqui et al., 2012).

\subsection{Effect of Fish Oil Administration on COX-2 Expression}

COX-2 expression in crypt epithelial cell of control group mice showed no alteration from the first month to the fourth month. Decreasing in the expression of COX-2 was found in administration of low dose fish oil with in the fourth month, meanwhile in the medium dose administration was found since the second month. Administration of high dose fish oil accelerates the decreasing of COX-2 expression, which has been achieved since the first month (Figure 3). Generally, fish oil administration to AOM and DSS-induced mice resulted in decreasing of COX-2 expression in the second month using medium doses. Thus, decreasing expression of COX-2 in colon crypt epithelial cells of mice had been given fish oil was parallel with the decreasing of iNOS expression which occurs in the second month using a dose of $3 \mathrm{mg} /$ day.

This result is consistent with previous research using arachidonic acid on mice-induced AOM, which revealed that the administration of $\omega-3$ decreased the expression of $\mathrm{COX}-2$ (Burlamaqui et al., 2012). Other studies have also reported that administration of $\omega-3$ derived from fish oil also has the potential to inhibit the occurrence of colorectal cancer. This inhibition are also in line with the decreasingof the expression of COX-2 in colonic crypt 
epithelial cells (Reddy, 2004). A research involving $\omega$-3 PUFA in colorectal cancer treatment concluded that there was inhibition of cancer development through the suppression of COX-2 expression in colon tissue (Hardman, 2002).

Correlation between colorectal carcinogenesis with the increase of COX-2 expression on transgenic mice had been reported (Ishikawa \& Herschman, 2010). Other research that provided similar result, showed that COX-2 expression in transgenic mice colon epithel was inhibited by the administration of $\omega-3$ PUFA. Feeding the colitis transgenic mice with desaturated fatty acid showed the decrease of COX-2 expression (Jia et al., 2008). Addition of fish oil in diet affected to reduced PGE2 and PGE3 as mediators which plays a role in inflammation and the increase of colon cell apoptosis (Vanamala et al., 2008). Meanwhile, there was a research using patient's colorectal cancer tissue sample, which showed no correlation between COX-2 expression and cancer patient's endurance. Apparently there was only $37 \%$ of the cancer patient's tissue sample which had a positive COX-2 expression (Shin, et al., 2014). A more controversial report of transgenic mice experiment stated that COX-2 stimulate the stage of tumor progression, and had no role at initiation stage (Al-Salihi et al., 2009). Enhancement of COX-2 expression in the control group of our research showed that it surpassed the inititation stage as the time passed.

This research shows fish oil could reduce inflammatory process. Some literatures mentioned that fish oil containing unsaturated fatty acids could reduce the level of inflammation in inflammatory bowel diseases/IBD (Gravaghi et al., 2011; Al-Salihi et al., 2009). Fish oil can influence the responsible cells in inflammation reaction through variety of mechanism, such as interfering the lipid complex, lipoprotein, hormone, and responsible metabolite in inflammation reactions. Fish oil PUFA have direct influence to inflammatory cells through fatty acid receptor at the cell surface and intracellular, and then influencing the transcriptional factor like peroxisome proliferator activated receptors (PPARs). Besides, PUFA can be oxidized by enzymatic or non-enzymatic process, and the derived substance will act directly at the surface receptor of inflammatory cell (Vanamala et al., 2008).

It has been reported that the changes of linoleic acid (LA) to arachidonic acid (AA) was inhibited by EPA, DHA and ALA that is contained in fish oil. AA compete with EPA, the substrate of COX-2 in the formation of PG and thromboxane (TX), and as substrate of lipooxigenase (LOX) enzyme in the formation of leukotrienes (Sasazuki et al., 2011). PG, TX, and leucotriene are proteins that play a role in inflammation reaction and proliferation, but the three EPA-derived proteins are lacking the ability to stimulate the inflammation reaction and proliferation. In addition, EPA and DHA have the ability to inhibit the production of COX-2 protein that inhibits the production of those three proinflammatory and proproliferation protein. It has been known that inflammation reaction and proliferation related with tumor development (Butler et al., 2009; Daniel et al., 2009).

\subsection{Effect of Fish Oil on the $\beta$-catenin Expression}

$\beta$-catenin is a protein that plays a role in colorectal cancer carcinogenesis. The enhance of $\beta$-catenin expression in the cytoplasm and nuclear of crypt epithel cells was parallel with carcinogenesis process. $\beta$-catenin is a molecule responsible in cell adhesion, mediated by E-cadherin, and Wnt-APC transduction pathway (Moon et al., 2004). The existency of $\beta$-catenin in cellular membrane, cytoplasm, and nuclear determine the adhesion ability and 
cellular pathway. In normal state, $\beta$-catenin is found abundantly in the cell membrane, small amount in the cytoplasm and nuclear. The accumulation of $\beta$ - catenin in the cytoplasm and nucleus of cells occurs due to mutations in the APC gene, $\beta$ - atenin or axin. Mutations in these genes are associated with the occurrence of colorectal carcinogenesis. The aberrant expression of $\beta$-catenin was found in dysplasia and colorectal cancer in AOM and DSS-induced mice, and in people who suffer from colon cancer and colitis related-dysplasia (Serafino et al., 2014). Our result showed an alteration of $\beta$-catenin expression, by immunohistochemistry staining (Figure 4). In the AOM and DSS-induced mice which were not treated by fish oil, the expression of $\beta$-catenin has mostly been found in cytoplasm, in the first month until fourth month. $\beta$-catenin expression in this group was parallel with the increasing in colon tissue dysplasia stage (Kusmardi et al., 2014).

From the three colorectal carcinogenesis protein marker expression, overall showed that the administration of fish oil reduce the three protein expression. The uniformity showed an interrelated process between the three proteins. Nitric oxide (NO) and prostaglandin (PG) are inflammatory mediator that influence inflammation pathogenesis. At the state of increasing NO and PG level, the increase of iNOS and COX-2 expression was found in colon mucosa epithel as well (Ishikawa \& Herschman, 2010). So did in the human colon malignancy which was preceded by the inflammation and in the DSS induced-mice, there was increasing iNOS and COX-2 expression in colon epithel. The explanation of this fact is due to the interaction between endogenous NO with COX-2, and between $\beta$-catenin/APC and COX-2 pathway. $\beta$-catenin/APC was reported to have a role in inducing COX-2 increased level that mediated by NP in colon epithel (Ridnour et al., 2008). It was also reported that $\beta$-catenin/Tcf-4 complex activated the PEA3 transcription factor which would stimulate COX-2 expression (Sergei et al., 2010).

\section{Conclusion}

Administration of fish oilin mice induced by AOM and DSS are intended to undergo colorectal preneoplasia development through inflammation, as well as to decrease the expression of iNOS and COX-2 in epithelial cells of the colonic mucosal crypts. Decreasing inexpression ofbothproteinshas been achievedin second month in the group administered by fish oil in medium dose. While the effect of medium dose of fish oil on the expression of $\beta$-catenin has been reached in the fourth month. Nevertheless, the trend of decreasing expression of $\beta$-catenin has been observedin the second month. Thus, administration of fish oil on murine colorectal preneoplasia induced by AOM and DSS, showed most effective inhibition in the second month, using amediumdose ( $3 \mathrm{mg} /$ day).

\section{Refferences}

Al-Salihi, M. A., Terrece, P. A., Doan, T., Reichert, E. C., \& Rosenberg, D. W. (2009). Transgenic expression of cyclooxygenase- 2 in mouse intestine epithelium is insufficient to initiate tumorigenesis but promotes tumor progression. Cancer Lett, 273, 225-32. http://dx.doi.org/10.1016/j.canlet.2008.08.012

Burlamaqui, I. M., Dornelas, C. A., Valença, J. T., Mota, D. M., \& Mesquita, F. J. (2012). Effect of a hyperlipidic diet rich in omegas 3,6 and 9 on aberrant crypt formation in rat 
$\begin{array}{lllll}\text { colonic } \text { mucosa. } & \text { Acta } & \text { 30-6. }\end{array}$ http://dx.doi.org/10.1590/S0102-86502012000100006

Butler, L. M., Wang, R., Koh, W-P., Stern, M. C., \& Yuan, J-M. (2009). Marine n-3 and saturated fatty acids in relation to risk of colorectal cancer in Singapore Chinese: A prospective study. Int J Cancer, 124(3), 678-686. http://dx.doi.org/10.1002/ijc.23950

Daniel, C. R., McCullough, M. L., Patel, R. C., Jacobs, E. J., \& Flanders, W. D. (2009). Dietary intake of $\omega-6$ and $\omega-3$ fatty acids and risk of colorectal cancer in a prospective cohort of U.S. men and women. Bioma Cancer Epidemiol rkers Prev, 18(2), 23-42. http://dx.doi.org/10.1158/1055-9965.EPI-08-0750

Gochman, E., Mahajna, J., Shenzer, P., Dahan, A., \& Blatt, A. (2012). The expression of iNOS and nitrotyrosine in colitis and colon cancer in humans. Acta Histochem, 114, 827-835. http://dx.doi.org/10.1016/j.acthis.2012.02.004

Gravaghi, C., La Perle, K. M. D., Ogrodwski, P., Kang, J. X., \& Quimby, F. (2011). Cox-2 expression, PGE2 and cytokines production are inhibited by endogenously synthesized n-3 PUFAs in inflamed colon of fat-1 mice. $J$ Nutr Biochem, 22, 360-5. http://dx.doi.org/10.1016/j.jnutbio.2010.03.003

Hardman, W. E. (2002). Omega-3 fatty acids to augment cancer therapy. J Nutr, 132, 3508S-3512S.

Ishikawa, T-O, \& Herschman, H. R. (2010). Tumor formation in a mouse model of colitis-associated colon cancer does not require COX-1 or COX-2 expression. Carcinogenesis, 31, 729-36. http://dx.doi.org/10.1093/carcin/bgq002

Jia, Q. J. R., Smith, R., Weeks, B. R., \& Callaway, E. (2008). Reduced colitis-associated colon cancer in fat-1 (n-3 fatty acid desaturase) transgenic mice. Cancer Res, 68, 3985-91. http://dx.doi.org/10.1158/0008-5472.CAN-07-6251

Kusmardi, Priosoeryanto, B. P., Harlina, E., \& Cornain, S. (2014). Inhibition activities of fish oil in dysplastic crypt of mice induced by azoxymetane and dextran sodium sulfate. Indones $\mathrm{J}$ Pharm Sci., 12(2) (in press).

Moon, R. T., Kohn, A. D., De Ferrari, G. V., \& Kaykas, A. (2004). WNT and beta-catenin signalling: diseases and therapies. Nat Rev Genet, 5, 691-701. http://dx.doi.org/10.1038/nrg1427

Moreira, A. P., Sabarense, C. M., Dias, C. M., Lunz, W., \& Natali, A. J. (2009). Fish oil ingestion reduces the number of aberrant crypt foci and adenoma in 1,2-dimethylhydrazine-induced colon cancer in rats. Braz J Med Biol Res, 42(12), 1167-72. http://dx.doi.org/10.1590/S0100-879X2009007500015

Ridnour, L. A., Thomas, D. D., Switzer, C., Flores-Santana, W., \& Isenberg, J. S. (2008). Molecular mechanisms for discrete nitric oxide levels in cancer. Nitric Oxide, 19, 73-76. http://dx.doi.org/10.1016/j.niox.2008.04.006 
Reddy, B. S. (2004). Mini Review: Omega-3 fatty acid in colorectal cancer prevention. Int J Cancer, 112, 1-7. http://dx.doi.org/10.1002/ijc.20320

Serafino, A., Moroni, N., Zonfrillo, M., Andreola, F., \& Mercuri, L. (2014). WNT-pathway components as predictive markers useful for diagnosis, prevention and therapy in inflammatory bowel disease and sporadic colorectal cancer. Oncotarget, 5(4), 978-92.

Sasazuki, S., Inoue, M., \& Iwasaki, M. (2011). Intake of n-3 and n-6 polyunsaturated fatty acids and development of colorectal cancer by subsite: Japan Public Health Center-based prospective study. Int J Cancer, 129, 1718-29. http://dx.doi.org/10.1002/ijc.25802

Sergei, I. G., Florian, R. G., \& Karin, M. (2010). Immunity, Inflammation, and Cancer. Cell, 140, 883-899. http://dx.doi.org/10.1016/j.cell.2010.01.025

Shin, I. Y., Sung, N. Y., Lee, Y. S., Kwon, T. S., \& Si, Y. L. (2014). The expression of multiple proteins as prognostic factors in colorectal cancer: cathepsin D, p. 53, COX-2, epidermal growth factor receptor, C-erbB-2, and Ki-67. Gut and liver, 8(1), 13-23. http://dx.doi.org/10.5009/gnl.2014.8.1.13

Suzuki, R., Kohno, H., Sugie, S., Nakagama, H., \& Tanaka, T. (2006). Strain differences in the susceptibility to azoxymethane and dextran sodium sulfate-induced colon carcinogenesis in mice. Carcinogenesis, 27, 162-169. http://dx.doi.org/10.1093/carcin/bgi205

Tanaka, T., Kohno, H., Suzuki, R., Yamada, Y., \& Sugie, S. (2003). A novel inflammation-related mouse colon carcinogenesis model induced by azoxymethane and $\begin{array}{llll}\text { dextran sodium } \quad \text { sulfate. } & \text { Cancer } i, & 94, & \text { 965-973. }\end{array}$ http://dx.doi.org/10.1111/j.1349-7006.2003.tb01386.x

Vanamala, J., Glagolenko, A., Yang, P., Carroll, R. J., \& Murphy, M. E. (2008). Dietary fish oil and pectin enhance colonocyte apoptosis in part through suppression of PPAR $\{$ delta\}/PGE2 and elevation of PGE3. Carcinogenesis, 29, 790-6. http://dx.doi.org/10.1093/carcin/bgm256

Walker, R. A. (2006). Quantification of immunohistochemistry-issues concerning methods, utility and semiquantitative assessment I. Histopathology, 49(4), 406-10. http://dx.doi.org/10.1111/j.1365-2559.2006.02514.x

\section{Copyright Disclaimer}

Copyright reserved by the author(s).

This article is an open-access article distributed under the terms and conditions of the Creative Commons Attribution license (http://creativecommons.org/licenses/by/3.0/). 